\title{
De mededingingsregels tijdens de Covid-19- crisis: een flexibel instrument voor de bescherming van de interne markt
}

\author{
Mr. M.C. van Heezik, mr. drs L.N.M. van Uden en mr. L.G.J. Fiorilli*
}

De mededingingsregels, waaronder de staatssteunregels, bieden ruimte aan overheden en ondernemingen om de ingrijpende economische gevolgen als gevolg van de Covid-19-crisis op te vangen. In tijdelijke kaders heeft de Europese Commissie uiteengezet welke bijzondere steunmaatregelen en welke samenwerkingsvormen tussen concurrerende ondernemingen zijn toegestaan. Om snel ingrijpen mogelijk te maken, heeft de Commissie voorzien in flexibele procedures die op korte termijn rechtszekerheid bieden. In deze bijdrage bespreken wij de specifieke invulling van de mededingingsregels in de tijdelijke kaders en gaan wij in op de vraag wat de tijdelijke materiële en procedurele flexibiliteit betekent voor de toekomst van deze regels.

\section{Inleiding}

Deze bijdrage gaat over de inzet van de mededingingsregels waaronder de staatssteunregels als instrument om de interne markt te beschermen tegen de ingrijpende economische gevolgen van de uitbraak van het Covid-19-virus. De zogenoemde 'inperkingsmaatregelen' van lidstaten om de verspreiding van dit virus tegen te gaan (o.a. social distancing, reis- en invoerbeperkingen, quarantaines en lockdomns), hebben tot gevolg gehad dat een groot deel van de vraag is weggevallen. Ondernemingen zijn hierdoor geconfronteerd met overschotten en grote verliezen. Andere ondernemingen, hoofdzakelijk in de medische sector en de levensmiddelenindustrie, werden juist geconfronteerd met tekorten als gevolg van de explosieve toename van de vraag waaraan niet kon worden voldaan door enerzijds de beperkingen in de handel en aanvoer en anderzijds capaci-

Mr. M.C. (Greetje) van Heezik is advocaat bij Houthoff te Brussel. Mr. drs. L.N.M. (Lumine) van Uden is advocaat bij Houthoff te Amsterdam. Mr. L.G.J. (Lorenzo) Fiorilli is advocaat bij Houthoff te Brussel. teitsgebrek. Daarnaast heeft de Covid-19-crisis grote onzekerheid veroorzaakt ten aanzien van investeringen en worden ondernemingen geconfronteerd met liquiditeitsbeperkingen. ${ }^{1}$

De mededingingsregels bieden flexibiliteit om zowel procedureel als materieel 'mee te buigen' met de ingrijpend gewijzigde economische omstandigheden en vormen een belangrijk instrument bij het ondersteunen van ondernemingen en de nationale economieën. De Europese Commissie ('Commissie') heeft in tijdelijke kaders uiteengezet op welke wijze de mededingingsregels tijdens de crisis moeten worden toegepast en welke materiële randvoorwaarden daarbij gelden.

In deze bijdrage bespreken wij de specifieke invulling van de mededingingsregels in de tijdelijke kaders en gaan wij in op de vraag wat deze tijdelijke materiële en procedurele flexibiliteit betekent voor de toekomst van deze regels. Daarbij bespreken wij eerst specifiek de staatssteunregels, gaan wij daarna in op het kartelverbod en misbruik van machtspositie en geven wij in de laatste paragraaf een conclusie.

\section{Toepassing staatssteunregels in de huidige Covid-19-crisis}

De Commissie heeft zeer snel duidelijkheid gegeven over de toepasselijkheid van de staatssteunregels op de maatregelen van lidstaten ter ondersteuning van de nationale economieën. ${ }^{2}$ Zo heeft de Commissie erop gewezen dat het staatssteuntoezicht niet van toepassing is op: ${ }^{3}$

1. Mededeling van de Commissie, Gecoördineerde economische respons op de uitbraak van Covid-19, $\operatorname{COM}(2020) 112$ final, p. 3.

2. Mededeling van de Commissie, Gecoördineerde economische respons op de uitbraak van Covid-19, $\operatorname{COM}(2020) 112$ final.

3. Zoals de Tijdelijke Noodmaatregel Overbrugging voor Werkgelegenheid (NOW). Mededeling van de Commissie, Gecoördineerde economische respons op de uitbraak van Covid-19, $\operatorname{COM(2020)} 112$ final, p. 11. 
- generieke maatregelen, zoals een algeheel betalingsuitstel voor belastingen of loonsubsidies voor alle ondernemingen. Deze maatregelen resulteren immers niet in een selectief voordeel voor één of meer ondernemingen;

- maatregelen gericht op consumenten, zoals de vergoeding aan consumenten van geannuleerde diensten of tickets. Voorwaarde is dat deze maatregelen ondernemingen niet direct of indirect bevoordelen; ${ }^{4}$

- overheidsmaatregelen die geen bevoordeling opleveren, zoals leningen of garanties tegen marktconforme premies $^{5}$ of maatregelen die een zeer gering voordeel opleveren (zogenoemde de-minimissteun) ${ }^{6}$

Alle andere steunmaatregelen ${ }^{7}$ moeten in beginsel bij de Commissie worden aangemeld met uitzondering van de vrijgestelde steun. ${ }^{8}$ Naast steun op grond van de bestaande staatssteunkaders, ${ }^{9}$ zoals reddings- en herstructureringssteun, ${ }^{10}$ heeft de Commissie aangegeven dat lidstaten gebruik kunnen maken van de bijzondere uitzonderingsmogelijkheden die zijn neergelegd in artikel 107 lid 2 onder b Verdrag betreffende de Werking van de Europese Unie (VWEU) (voor steunmaatregelen tot herstel van de schade veroorzaakt door natuur-

4. Uitgangspunt van de Commissie lijkt te zijn dat het hier gaat om compensatie die niet door de betrokken aanbieders hoeft te worden betaald. Bestaat er wel een dergelijke compensatieverplichting, dan vormt de compensatie van consumenten een indirect voordeel voor ondernemingen dat wel onder het staatssteuntoezicht valt. Vgl. ook Mededeling van de Commissie betreffende het begrip 'staatssteun' in de zin van artikel 107 lid 1, van het Verdrag betreffende de werking van de Europese Unie, PbEU 2016, C 262/01, par. 4.3 en de daarin aangehaalde rechtspraak.

5. Conform de Mededeling van de Commissie betreffende de toepassing van de artikelen 87 en 88 van het EG-Verdrag op staatssteun in de vorm van garanties, PbEU 2008, C 155/02 respectievelijk de Mededeling van de Commissie over de herziening van de methode waarmee de referentie- en disconteringspercentages worden vastgesteld, $P b E U$ 2008, C 14/02.

6. Zie o.a. Verordening (EU) nr. 1407/2013 van de Commissie van 18 december 2013 betreffende de toepassing van de art. 107 en 108 van het Verdrag betreffende de werking van de Europese Unie op deminimissteun, PbEU 2013, L 352/1 en Verordening (EU) nr. 360/2012 van de Commissie van 25 april 2012 betreffende de toepassing van de art. 107 en 108 van het Verdrag betreffende de werking van de Europese Unie op de-minimissteun verleend aan diensten van algemeen economisch belang verrichtende ondernemingen, PbEU 2012, L 114/8.

7. Van een steunmaatregel in de zin van art. 107 lid 1 VWEU is sprake indien: (1) een niet-marktconform voordeel, ongeacht de vorm, wordt toegekend aan één of meer ondernemingen, dat (2) met staatsmiddelen wordt gefinancierd en aan de Staat is toe te rekenen en dat (3) de concurrentie kan vervalsen en (4) het handelsverkeer tussen de lidstaten potentieel ongunstig kan beïnvloeden.

8. Zie o.a. Verordening (EU) nr. 651/2014 van de Commissie van 17 juni 2014 waarbij bepaalde categorieën steun op grond van de artikelen 107 en 108 van het Verdrag met de interne markt verenigbaar worden verklaard, PbEU 2014, L 187/1.

9. Het gaat om de kaders die invulling geven aan de uitzonderingsgrond van art. 107 lid 3 onder c VWEU voor steun ter stimulering van ontwikkeling van bepaalde vormen van economische bedrijvigheid of regionale economieën.

10. Mededeling van de Commissie, Richtsnoeren voor reddings- en herstructureringssteun aan niet-financiële ondernemingen in moeilijkheden, PbEU 2014, C 249/1 (hierna: Richtsnoeren voor reddings- en herstructureringssteun). rampen of andere buitengewone gebeurtenissen) en in artikel 107 lid 3 onder b VWEU (voor steunmaatregelen die tot doel hebben een ernstige verstoring van de economie van een lidstaat op te heffen). Hoewel artikel 107 lid 2 onder b VWEU op grond van de rechtspraak strikt dient te worden uitgelegd, ${ }^{11}$ kwalificeert de Commissie de Covid-19-uitbraak als een buitengewone, onvoorziene gebeurtenis met een aanzienlijke economische uitwerking. ${ }^{12}$ Indien is aangetoond dat de schade het rechtstreekse gevolg is van de Covid-19-uitbraak en de inperkingsmaatregelen, ${ }^{13}$ heeft de Commissie geen beoordelingsvrijheid, maar dient zij de voorgelegde steunmaatregelen goed te keuren. ${ }^{14}$ Beoordelingsruimte heeft de Commissie wel wanneer zij artikel 107 lid 3 onder b VWEU toepast. Deze uitzondering is alleen van toepassing indien sprake is van een exceptionele verstoring van de gehele economie van een lidstaat. ${ }^{15}$ Een dergelijke verstoring heeft de Commissie tijdens de financiële crisis aangenomen. ${ }^{16}$ De invulling van de onder deze uitzondering toegestane steunmaatregelen heeft de Commissie uitgewerkt in de Tijdelijke Kaderregeling die wij hierna bespreken. Dat de Commissie de toepassing van artikel 107 lid 2 onder b naast artikel 107 lid 3 onder b VWEU toestaat, is uniek en onderstreept de ingrijpende gevolgen van de Covid-19-crisis en het feit dat deze crisis, anders dan de financiële crisis, niet te wijten is aan de ondernemingen die zelf worden getroffen.

Op procedureel vlak past de Commissie een versnelde goedkeuringsprocedure toe. Indien nodig kan zij binnen 24 uur na ontvangst van een volledige aanmelding van

11. Zie o.a. HvJ 11 november 2004, zaak C-73/03, ECLI:EU:C:2004:711 (Spanje/Commissie), punt 36, HvJ 23 februari 2006, gevoegde zaken C-346/03 en C-529/03, ECLI:EU:C:2006:130, Jur. 2006, p. I-01875, (Atzeni e.a.), punt 79 en Commissiebesluit van 23 december 2008, $\mathrm{N} \mathrm{643/2008,} \mathrm{Special} \mathrm{measures} \mathrm{relating} \mathrm{to} \mathrm{meat} \mathrm{products} \mathrm{of} \mathrm{animal} \mathrm{ori-}$ gin from pigs following a dioxin contamination in Ireland, par. 26, 27 en 29.

12. Mededeling van de Commissie, Gecoördineerde economische respons op de uitbraak van Covid-19, $\operatorname{COM}(2020) 112$ final, p. 11. Zie ook Mededeling van de Commissie van 20 maart 2020, Tijdelijke Kaderregeling inzake staatssteun ter ondersteuning van de economie vanwege de huidige COVID-19-uitbraak, PbEU 2020, C 91 I/01, punt 15 (hierna: Tijdelijke Kaderregeling)

13. Tijdelijke Kaderregeling punt 15 en Mededeling van de Commissie van 29 juni 2020, Derde wijziging van de tijdelijke kaderregeling inzake staatssteun ter ondersteuning van de economie vanwege de huidige COVID-19-uitbraak, PbEU 2020, C 218/03, punt 13 (ingevoegd punt 15bis). Zie o.a. steunmaatregelen SA.56774 Compensation scheme to companies exposed to large turnover decline related to COVID-19; SA. 57061 Sweden - Compensation for the damage caused by the COVID-19 outbreak to Scandinavian Airlines en SA.57178 Romania COVID-19 - Aid to Timișoara Airport.

14. Art. 107 lid 2 onder b VWEU bepaalt dat de steunmaatregelen tot herstel van de schade veroorzaakt door natuurrampen of andere buitengewone gebeurtenissen verenigbaar zijn met de interne markt.

15. HvJ 17 september 1980, zaak C-730/79, ECLI:EU:C:1980:209, Jur. 1980, p. I-02671 (Philip Morris), punt 25. Zie ook F.J. Säcker en F. Montag (red.), European State Aid Law. A Commentary, C.H. Beck, Hart, Nomos 2016, p. 283 en 284.

16. Zie o.a. het tijdelijke steunkader voor de reële economie. Mededeling van de Commissie van 11 januari 2011, Tijdelijke kaderregeling van de Unie inzake staatssteun ter stimulering van de toegang tot financiering in de huidige financiële en economische crisis, PbEU 2011, C 6/05. 
staatssteun van een lidstaat een besluit afgeven. ${ }^{17} \mathrm{De}$ Commissie heeft daarnaast een speciale e-mailbox en een speciaal telefoonnummer in het leven geroepen waar lidstaten met al hun vragen terecht kunnen en al in een vroeg stadium met de Commissie in overleg kunnen treden. ${ }^{18}$ Door deze procedurele flexibiliteit en het opschalen van het aantal beschikbare ambtenaren - onder wie ambtenaren die tijdens de financiële crisis de staatssteunmaatrelen hebben beoordeeld - heeft de Commissie sinds het begin van de Covid-19-uitbraak ruim 256 goedkeuringsbesluiten ${ }^{19}$ kunnen afgeven.

\section{Tijdelijke Kaderregeling - flexibel staatssteunregime tijdens de Covid-19-crisis}

\section{Eerste versie: liquiditeitssteun}

De eerste versie van de Tijdelijke Kaderregeling is vooral gericht op het verbeteren van de liquiditeit van ondernemingen en introduceert daartoe vijf typen steunmaatregelen: (1) steun tot maximaal $€ 800.000$ per onderneming in de vorm van rechtstreekse subsidies, selectieve belastingvoordelen, betalingsregelingen, terugbetaalbare voorschotten, leningen, garanties of eigen vermogen; (2) staatsgaranties voor maximaal 90 procent van leningen; (3) gesubsidieerde leningen; (4) garanties of leningen via kredietinstellingen en (5) kortlopende exportkredietverzekeringen. De steunmaatregelen van type (1) moeten worden vormgegeven als een steunregeling op grond waarvan ondernemingen binnen één of meer sectoren in aanmerking komen voor de steun. ${ }^{20}$ Deze voorwaarde heeft tot doel de capaciteit van de Commissie zo veel mogelijk te benutten voor omvangrijkere steunmaatregelen. ${ }^{21}$ Voor de andere

17. Volgens de reguliere meldingsprocedure neemt de Commissie op zijn vroegst twee maanden na ontvangst van de formele melding een besluit. Zie ook art. 4 lid 5 Verordening (EU) 2015/1589 van de Raad van 13 juli 2015 tot vaststelling van nadere bepalingen voor de toepassing van artikel 108 van het Verdrag betreffende de werking van de Europese Unie, PbEU 2015, L 248/9 (Procedureverordening).

18. Zie https://ec.europa.eu/competition/state_aid/what_is_new/covid_ 19.html.

19. Zie het overzicht van de goedgekeurde steunmaatregelen op de website van het Directoraat-Generaal Mededinging: https://ec.europa.eu/ competition/state_aid/what_is_new/State_aid_decisions_TF_and_107_ 2b_107_3b_107_3c.pdf) (laatst geraadpleegd op 10 augustus 2020.

20. Art. 1 sub d Procedureverordening definieert 'steunregeling' als 'elke regeling op grond waarvan aan ondernemingen die in de regeling op algemene en abstracte wijze zijn omschreven, individuele steun kan worden toegekend zonder dat hiervoor nog uitvoeringsmaatregelen vereist zijn, alsmede elke regeling op grond waarvan steun die niet gebonden is aan een specifiek project voor onbepaalde tijd en/of voor een onbepaald bedrag aan een of meer ondernemingen kan worden toegekend'.

21. Dit is conform het adagium 'big on big and small on small' dat de Commissie in het kader van de Modernisering van het staatssteunbeleid als uitgangspunt heeft geformuleerd en op grond waarvan de Commissie het staatssteuntoezicht wenst te reserveren voor de steunmaatregelen met de grootste uitwerking op de interne markt. Zie ook Mededeling van de Commissie inzake 'De modernisering van het EU-staatssteunbeleid', COM/2012/0209 final, par. 2.2. steunvormen laat de Tijdelijke Kaderregeling ook de aanmelding van steun aan individuele ondernemingen toe, zoals de liquiditeitssteun aan Renault en Air France. $^{22}$ De grootste bulk van de steunmaatregelen betreft liquiditeitssteun in de vorm van leningen en garanties. ${ }^{23}$ Diverse lidstaten hebben zogenoemde 'parapluregelingen' ter goedkeuring voorgelegd waarmee zij op nationaal niveau veel vrijheid hebben in het toekennen van steun en de benodigde capaciteit bij de Commissie voor de beoordeling beperkt blijft. ${ }^{24}$

De Tijdelijke Kaderregeling is alleen van toepassing op ondernemingen die op 31 december 2019 niet in moeilijkheden verkeerden. De steun aan ondernemingen die voor de Covid-19-uitbraak reeds in financiële moeilijkheden verkeerden, moet voldoen aan de (reguliere) voorwaarden voor reddings- en herstructureringssteun. ${ }^{25}$

\section{Eerste verruiming: volksgezondheids- en werkgelegenheidssteun}

De eerste verruiming van de Tijdelijke Kaderregeling ${ }^{26}$ omvat onder andere steunmogelijkheden voor onderzoek en ontwikkeling naar vaccins en geneesmiddelen en investeringen gericht op de productie van Covid-19producten, zoals (beademings)apparatuur, ontsmettings- of beschermingsmiddelen en de bouw en opschaling van testfaciliteiten. ${ }^{27}$ Daarnaast introduceert deze verruiming aanvullende mogelijkheden voor gerichte liquiditeitssteun ten behoeve van het behoud van werkgelegenheid, zoals loonsubsidies en betalingsuitstel voor belastingen en voor sociale premies en loonsubsidies.

Tweede verruiming: solvabiliteitssteun

Door het voortduren van de crisis is naast de liquiditeit ook de solvabiliteit van veel ondernemingen in gevaar gekomen. Met de tweede verruiming zijn daarom herkapitalisatiesteun en steun in de vorm van achtergestelde schuld geïntroduceerd. ${ }^{28}$ Vanwege het concurrentiever-

22. Commissiebesluiten inzake steunmaatregelen SA.57082 - Cadre temporaire 107(3)(b) - Garantie et prêt d'actionnaire au bénéfice d'Air France en SA.57134 COVID 19: Aide sous forme de garanties de prêts au profit du groupe Renault.

23. Op 10 augustus betrof dit 183 besluiten.

24. Dit betreft onder andere Frankrijk (SA.56985 - Régime cadre temporaire au soutien des entreprises dans la crise du Covid 19); Duitsland (SA. 57100 - COVID-19 - Federal Framework Scheme 'Aid for Covid-19 related $R \& D$, investments in testing infrastructures and production facilities' ('Bundesregelung Forschungs-, Entwicklungs- und Investitionsbeihilfen')); Hongarije (SA.57468 - COVID-19: Umbrella scheme of direct grants provided from the appropriations managed at the level of ministries' budgetary chapters), Italië (SA.57021 (2020/N, ex 2020/PN) - COVID-19: Regime Quadro) en het Verenigd Koninkrijk (SA.56841 COVID-19: Temporary Framework for UK authorities).

25. Vgl. Commissiebesluit inzake steunmaatregel SA.57369 - Aid to TAP.

26. Mededeling van de Commissie van 3 april 2020, Wijziging van de tijdelijke kaderregeling inzake staatssteun ter ondersteuning van de economie vanwege de huidige COVID-19-uitbraak, PbEU 2020, C 112 I/01 (hierna: 'Eerste wijziging Tijdelijke Kaderregeling').

27. Tot op heden zijn zestien steunmaatregelen gericht op investeringen in het onderzoek naar en de productie van Covid-19-gerelateerde producten, zoals persoonlijke beschermingsmiddelen en vaccins, door de Commissie goedgekeurd.

28. Mededeling van de Commissie van op 8 mei 2020, Wijziging van de tijdelijke kaderregeling inzake staatssteun ter ondersteuning van de eco- 
valsende karakter is herkapitalisatiesteun alleen toegestaan indien andere steunvormen niet toereikend zijn. Daarnaast gelden strikte voorwaarden ten aanzien van de geschiktheid, de omvang, de vergoeding en de exit van de Staat uit het vermogen van de betrokken ondernemingen. De strikte governancevoorwaarden ${ }^{29}$ waarborgen dat de steun uitsluitend wordt gebruikt om de onderneming weer levensvatbaar te maken en stimuleren een snelle aflossing. ${ }^{30}$ Zolang niet ten minste 75 procent van de herkapitalisatiemaatregelen is afgelost, geldt onder andere een bonusverbod voor het management ${ }^{31}$ en een acquisitieverbod van meer dan 10 procent in concurrenten of andere marktdeelnemers in de branche. ${ }^{32}$ Voorts mag pas dividend worden uitgekeerd zodra de schuld volledig is afgelost.

Ondernemingen die meer dan 250 miljoen euro aan herkapitalisatiesteun ontvangen, moeten jaarlijks rapporteren op welke wijze de steun is besteed aan de vereiste maatregelen en investeringen ten behoeve van deze transitie.

Ten slotte zijn bij verlening van meer dan 250 miljoen euro aan herkapitalisatiesteun aan een onderneming met aanzienlijke marktmacht, structurele of gedragstoezeggingen vereist. Deze remedies moeten voorkomen dat de ondersteuning van het kunstmatig voortbestaan van de marktmacht de markttoegang voor andere ondernemingen beperkt. ${ }^{33}$ Hoe ingrijpend de toezeggingen moeten zijn, hangt onder andere af van de omvang en het relatieve belang van de begunstigde onderneming op de markt en de kenmerken van de betrokken markt. In de Tijdelijke Kaderregeling verwijst de Commissie naar de Mededeling inzake remedies in het kader van de concentratiecontrole. ${ }^{34}$ Tot op heden heeft alleen Lufthansa als remedie voor de herkapitalisatiesteun 24 landings- en startrechten op de luchthavens van Frankfurt en München moeten afstoten. ${ }^{35}$

In verband met het concurrentieverstorende karakter van de herkapitalisatiesteun mag deze steun voorts alleen worden verstrekt indien daarmee een gemeenschappelijk belang wordt gediend. De Tijdelijke Kaderregeling bevat geen definitie van het vereiste 'gemeen-

nomie vanwege de huidige COVID-19-uitbraak, PbEU 2020, C 164/03 (hierna: 'Tweede wijziging Tijdelijke Kaderregeling').

29. Tweede wijziging Tijdelijke Kaderregeling, punt 37 (ingevoegd punt 3.11.6.).

30. Richtsnoeren reddings- en herstructureringssteun, par. 83-85.

31. Tweede wijziging Tijdelijke Kaderregeling, punt 37 (ingevoegd punt 78)

32. Tweede wijziging Tijdelijke Kaderregeling punt 37 (ingevoegde punten 74 en 75).

33. Zie ook de vergelijkbare verplichting die tijdens de financiële sector gold: Mededeling van de Commissie betreffende het herstel van de levensvatbaarheid en de beoordeling van de herstructureringsmaatregelen in de financiële sector in de huidige crisis met inachtneming van de staatssteunregels, PbEU 2009, C 195/04, punt 28, 29 en 35-38.

34. Tweede wijziging Tijdelijke Kaderregeling, punt 37 (ingevoegd punt 72 , waarin wordt verwezen naar de mededeling inzake remedies in het kader van de concentratiecontrole (Mededeling van de Commissie betreffende op grond van Verordening (EG) nr. 139/2004 van de Raad en Verordening (EG) nr. 802/2004 van de Commissie aanvaardbare corrigerende maatregelen, PbEU 2008, C 267/1).

35. Commissiebesluit inzake steunmaatregel SA.57153 COVID-19 - Aid to Lufthansa (nog niet gepubliceerd). schappelijk belang', maar verwijst naar het voorkomen van sociale problemen en marktfalen als gevolg van een aanzienlijk verlies van werkgelegenheid, de verdwijning van een innovatieve onderneming of van een systeemrelevante onderneming of het voorkomen van verstoring van een belangrijke dienstverlening. Met deze voorbeelden geeft de Tijdelijke Kaderregeling nadere invulling aan de EU-doelstellingen van gemeenschappelijk belang die kunnen worden gediend met steunmaatregelen die een ernstige verstoring in de economie van een lidstaat, bedoeld in artikel 107 lid 3 onder b VWEU, beogen op te heffen. ${ }^{36}$ De introductie van het begrip 'systeemrelevante onderneming' in dit verband lijkt een variant op de 'systeembanken' die in de financiële crisis steun mochten ontvangen. Toch heeft deze term een iets andere lading omdat de term 'systeembank' verwijst naar de onderlinge horizontale systeemverwevenheid van het mondiale netwerk van financiële instellingen dat uniek is voor de financiële sector. ${ }^{37}$ De term 'systeemrelevante onderneming' lijkt vooral te doelen op ondernemingen die verweven zijn met de economie van een lidstaat. Het in stand houden van deze ondernemingen is van groot belang voor het herstel van het evenwicht in de reële economie van een lidstaat. Dat geldt tevens voor innovatieve ondernemingen en ondernemingen die een belangrijke rol vervullen in de dienstverlening die eveneens in aanmerking komen voor herkapitalisatiesteun. Blijkens de persberichten van de Commissie is de herkapitalisatiesteun die tot nu toe is verleend, gebaseerd op het belang van de onderneming voor de economie van de steunverlenende lidstaat en het voorkomen van 'verlies van de werkgelegenheid' en 'verstoring van een belangrijke dienstverlening'. ${ }^{38}$ In geen van deze besluiten lijkt derhalve sprake van een discussie over de kwalificatie van 'systeemrelevante onderneming'.

Derde verruiming: aanvullende steun voor microen kleine ondernemingen en stimulering particuliere investeringen

Met de derde verruiming ${ }^{39}$ wordt het uitgangspunt dat de Tijdelijke Kaderregeling alleen van toepassing is op ondernemingen die op 31 december 2019 niet in moei-

36. Vgl. ook de Richtsnoeren voor reddings- en herstructureringssteun aan niet-financiële ondernemingen in moeilijkheden, PbEU 2014, C 249/01, par. 3.1, waarin de voorwaarde wordt gesteld dat de steun gericht moet zijn op de EU-doelstellingen van gemeenschappelijk belang bestaande uit het voorkomen van sociale tegenspoed of het aanpakken van marktfalen of op het herstel van de levensvatbaarheid van de onderneming op lange termijn.

37. Mededeling van de Commissie betreffende de toepassing vanaf 1 augustus 2013 van de staatssteunregels op maatregelen ter ondersteuning van banken in het kader van de financiële crisis, PbEU 2013, C 216/1, punt 25. Zie ook Charalambos Savvides en Daniel Antoniiou, 'Ailing Financial Institutions: EC State Aid Policy Revisited', World Competition 2009, nr. 3, p. 347-366.

38. Zie o.a. de persberichten inzake de steun aan Deutsche Lufthansa d.d. 25 juni 2020, https://ec.europa.eu/commission/presscorner/detail/en/ IP_20_1179 en inzake de steun aan airBaltic d.d. 3 juli 2020, https:// ec.europa.eu/commission/presscorner/detail/en/ip_20_1274.

39. Mededeling van de Commissie van 29 juni 2020, Derde wijziging van de tijdelijke kaderregeling inzake staatssteun ter ondersteuning van de economie vanwege de huidige COVID-19-uitbraak, PbEU 2020, C 218/03 (hierna: 'Derde wijziging Tijdelijke Kaderregeling'). 
lijkheden verkeerden, losgelaten voor micro-ondernemingen en kleine ondernemingen en start-ups. Het risico op concurrentievervalsing door steun aan deze ondernemingen is zeer beperkt, terwijl juist innovatieve start-ups cruciaal zijn voor het economisch herstel. Daarnaast versoepelt de derde verruiming de governancevoorwaarden voor particuliere investeerders die significant bijdragen aan de kapitaalverhoging (ten minste 30 procent) tegen dezelfde voorwaarden als de Staat. Zo zijn het acquisitieverbod en het bonusverbod voor het management beperkt tot drie jaar en gelden soepelere voorwaarden voor dividenduitkeringen. ${ }^{40}$

\section{Vooruitblik}

De ervaring die de Commissie tijdens de financiële crisis heeft opgedaan, heeft haar in staat gesteld zeer snel de Tijdelijke Kaderregeling en de opeenvolgende verruimingen voor te stellen en een groot aantal steunmaatregelen goed te keuren. De snelle en flexibele aanpak heeft - net als de voorgestelde aanpak tijdens de financiële crisis ${ }^{41}$ - mede bijgedragen aan de brede steun voor de toepassing van de staatssteunregels ook in crisistijd. ${ }^{42}$ Op kortere termijn lijkt het aannemelijk dat het aantal steunmaatregelen van lidstaten nog verder zal toenemen. De Tijdelijke Kaderregeling is (vooralsnog) van toepassing tot en met 31 december 2020. Hoewel de inperkingsmaatregelen aanzienlijk zijn versoepeld, zijn de nationale economieën nog lang niet hersteld. Gezien de recente opleving van het Covid-19-virus kan bovendien niet worden uitgesloten dat nieuwe inperkingsmaatregelen zullen worden genomen om de verspreiding van het Covid-19-virus tegen te gaan, met alle economische gevolgen van dien. Aanvullende steunmaatregelen kunnen een uitbreiding of budgetverhoging van de reeds goedgekeurde steunmaatregelen betreffen. ${ }^{43}$ Het gaat hierbij voornamelijk om steunmaatregelen die gericht zijn op het verstrekken van liquiditeit in de vorm van garanties en gesubsidieerde leningen, het behoud van werkgelegenheid en Covid-19-gerelateerde investeringen. Daarnaast kan het gaan om maatregelen ter ondersteuning van individuele ondernemingen, die

40. Derde wijziging Tijdelijke Kaderregeling, punt 21 (ingevoegd punt 78bis, onderdeel c, sub (ii) en (iii)).

41. Zie de conclusies van de Europese Raad van 15 en 16 oktober 2008 (14368/08), punt 5. Zie ook de conclusies van de ECOFIN-Raad, 2894e zitting van de Raad Economische en Financiële Zaken Luxemburg, 7 oktober 2008 (C/08/279). Zie ook Mededeling van de Commissie aan de Europese Raad, COM(2008)800.

42. Zie o.a. de Gezamenlijke verklaring van de leden van de Europese Raad, d.d. 26 maart 2020. De toepassing van de staatssteunregels tijdens de Covid-19-crisis is nauwelijks ter discussie is gesteld. Alleen Oostenrijk opperde openlijk om de staatssteunregels tijdelijk buiten toepassing te laten. Zie de brief van de Oostenrijkse ministers aan vicevoorzitter Margrethe Vestager d.d. 21 april 2020: www.bmf.gv.at/dam/jcr:59acf089f903-43c5-ad46-752999b6336a/AT\%20position\%20on\%20State \%20Aid.pdf.

43. Zie o.a. besluit betreffende steunmaatregel SA.58096 COVID-19: Amendments to SA.56803 - Guarantee scheme. tot op heden beperkt in aantal zijn gebleven. ${ }^{44}$ Het gaat hierbij hoofdzakelijk om steun aan luchtvaartmaatschappijen, waarbij de prioriteit van lidstaten bij de 'nationale kampioenen' ligt. Een toename van individuele steunmaatregelen zal naar verwachting ook leiden tot meer beroepen tegen de goedkeuringsbesluiten van de Commissie door niet-gesteunde concurrenten. ${ }^{45}$ Tot op heden heeft alleen Ryanair beroepen tot nietigverklaring van de besluiten ingesteld ten aanzien van steunmaatregelen ten gunste van haar concurrenten. ${ }^{46}$ Ryanair stelt zich in al deze beroepen op het standpunt dat de steun in strijd is met het discriminatieverbod en het vrij verrichten van diensten en de vrijheid van vestiging. De Commissie gaat volgens Ryanair voorbij aan het feit dat de liberalisering van de luchtvervoersmarkt juist de ruimte heeft geboden aan pan-Europese lowbudgetluchtvaartmaatschappijen die een belangrijke rol vervullen voor de luchtvaartconnectiviteit. Uitgerekend deze ondernemingen komen niet in aanmerking voor compensatie van de schade als gevolg van de Covid-19-crisis. Hoewel het selectieve karakter van de individuele steunmaatregelen de discriminatie van concurrenten impliceert, zal de Commissie de proportionaliteit, het concurrentievervalsende karakter en de verenigbaarheid van de steun met de interne marktregels van de individuele steunmaatregelen kritisch moeten onderzoeken om vernietiging van haar besluiten te voorkomen. $^{47}$

Voor de langere termijn is de impact van de Tijdelijke Kaderregeling op de staatssteunregels ons inziens beperkt. De Covid-19-crisis is niet vergelijkbaar met de financiële crisis die door de financiële instellingen was veroorzaakt. De Tijdelijke Kaderregeling bevat ook geen vergelijkbare correctie, zoals de 'bail-in voorwaarde' die tijdens de financiële crisis is geintroduceerd om financiële instellingen financieel bij te laten dragen aan de steun. Deze voorwaarde is vervolgens ook in de richtsnoeren voor reddings- en herstructureringssteun opge-

44. Het gaat om zeventien van het totaal aantal genomen besluiten (tot en met 29 juli 2020: 234 besluiten), waarvan elf besluiten betrekking hebben op steun aan luchtvaartmaatschappijen.

45. Een beroep tegen een besluit tot goedkeuring van een steunregeling zal in veel gevallen niet voldoen aan de ontvankelijkheidsvoorwaarden dat de verzoeker individueel en rechtstreeks in zijn belang moet worden geraakt en zich in dat opzicht onderscheidt van alle andere ondernemingen.

46. Zaak T-388/20 tegen Besluit (EU) van de Europese Commissie van 11 april 2020 betreffende steunmaatregel SA.56812 (Zweden) - Garantieregeling voor leningen aan luchtvaartmaatschappijen, PbEU 2020, C 262/49; zaak T-259/20 tegen Besluit (EU) van de Europese Commissie van 31 maart 2020 betreffende steunmaatregel SA.56765 (Frankrijk) - Moratoire sur le paiement de taxes aéronautiques en faveur des entreprises de transport public aérien, zaken T-378/20 en T-379/20 tegen Besluit (EU) van de Europese Commissie van 15 april 2020 betreffende steunmaatregelen SA.56795 (Denemarken) en SA.57061 (Zweden) - Vergoeding van de door Scandinavian Airlines geleden schade als gevolg van de COVID 19-uitbraak en zaken T-388/20 en T-465/20 (nog niet gepubliceerd in het $P b E U$ ). Dit betreft de beroepen tegen de steunbesluiten inzake de herkapitalisatiesteun aan Lufthansa en de reddings- en herstructureringssteun aan TAP.

47. Op grond van de vaste rechtspraak mag de Commissie voorts alleen steun goedkeuren indien deze ook verenigbaar is met de andere interne marktregels. Zie o.a. Gerecht 26 februari 2019, zaak T-865/16, ECLI:EU:T:2019:113 (Fútbol Club Barcelona), punt 29. 
nomen. ${ }^{48}$ Wel heeft de Tijdelijke Kaderregeling de trend ingezet om via de steunmaatregelen de groene en digitale transitie zo veel mogelijk te stimuleren. Deze beleidsagenda, die voor een belangrijk deel is uitgewerkt in de Green Deal, ${ }^{49}$ bestond al voor de Covid-19-uitbrak en zou ook voor eind 2020 in diverse reguliere steunkaders worden verwerkt. ${ }^{50}$ Dat de Commissie via de staatssteunregels haar 'groene beleidsagenda' stimuleert, is niet nieuw ${ }^{51}$ maar consistent met de modernisering van het staatssteunbeleid die na de financiële crisis heeft plaatsgevonden. Volgens deze modernisering moet de focus liggen op 'goede steun' die gericht is op onder andere innovatie en groene technologie, en schade aan het milieu helpt te voorkomen. ${ }^{52}$ Hoewel de Tijdelijke Kaderregeling alleen aan herkapitalisatiesteun 'groene' voorwaarden verbindt, ${ }^{53}$ grijpen de lidstaten ook andere steunmaatregelen aan om ondernemingen te verplichten bij te dragen aan de klimaatdoelstellingen. Zo kregen Air France, Renault en KLM in ruil voor liquiditeitssteun de verplichting om de $\mathrm{CO}_{2}$-uitstoot te verlagen en de transitie naar milieuvriendelijkere vlieg- en voertuigen te realiseren. ${ }^{54}$ Dat via de staatssteunregels en -maatregelen op Europees en nationaal niveau beleidspolitiek wordt gevoerd, is een bewuste keuze die onlos-

48. Zie o.a. B.J. Drijber, 'Staatssteun in tijden van corona: hoe ver mag de geldkraan open?', Ondernemingsrecht 2020/63.

49. Zie https://ec.europa.eu/info/strategy/priorities-2019-2024/europeangreen-deal_nl.

50. Mededeling van de Commissie betreffende de verlenging van en wijzigingen in de richtsnoeren inzake regionale steunmaatregelen 2014-2020, de richtsnoeren inzake staatssteun ter bevordering van risicofinancieringsinvesteringen, de richtsnoeren inzake staatssteun ten behoeve van milieubescherming en energie 2014-2020, de richtsnoeren voor reddings- en herstructureringssteun aan ondernemingen in moeilijkheden, de mededeling inzake criteria voor de beoordeling van de verenigbaarheid met de interne markt van staatssteun ter bevordering van de verwezenlijking van belangrijke projecten van gemeenschappelijk Europees belang, de mededeling van de Commissie over de kaderregeling betreffende staatssteun voor onderzoek, ontwikkeling en innovatie, en de mededeling van de Commissie aan de lidstaten inzake de toepassing van de artikelen 107 en 108 van het Verdrag betreffende de werking van de Europese Unie op kortlopende exportkredietverzekering (2020/C 224/02). Deze herziening is in verband met de noodzaak van rechtszekerheid in de huidige crisissituatie met een jaar uitgesteld.

51. Ook tijdens de financiële crisis heeft de Commissie aangegeven dat de realisatie van de milieudoelstellingen een prioriteit moet blijven ondanks de financiële economische crisis. Het tijdelijke steunkader voor de reële economie voorzag daartoe in de mogelijkheid van productiesteun voor milieuvriendelijkere en energiezuinigere producten in overeenstemming met de Europa 2020-strategie. Zie Mededeling van de Commissie van 1 november 2011, Tijdelijke kaderregeling van de Unie inzake staatssteun ter stimulering van de toegang tot financiering in de huidige financiële en economische crisis, PbEU 2011, C 6/05, punt 2.5 .

52. Mededeling van de Commissie inzake 'De modernisering van het EUstaatssteunbeleid', COM/2012/0209 final, par. 2.1.

53. Tweede wijziging Tijdelijke Kaderregeling, punt 37 (ingevoegde punten 44, 45 en 83). Zie ook par. 3.1.2. van de Richtsnoeren voor reddingsen herstructureringssteun waarin de voorwaarden voor het herstructureringsplan en herstel van de levensvatbaarheid op lange termijn zijn opgenomen.

54. Zie www.france24.com/en/20200424-french-government-announceshistoric-\%E2\%82\%AC7-billion-aid-pakage-for-air-france-klm en www. wsj.com/articles/renault-lines-up-state-aid-as-it-emerges-from-corona virus-lockdown-11587640923. Zie ook T. Wilson en P. Gnatzy, 'COVID-19 and EU State aid recapitalisation', Kluwer Competition Law Blog. Zie 'Steunpakket KLM voor 3,4 miljard, banenverliesonvermijdelijk', Nieuwsbericht NOS 26 juni 2020. makelijk is verbonden met het herstel van de levensvatbaarheid van de gesteunde ondernemingen en daarmee met het herstel van de nationale en Europese economie. Ten slotte heeft de Covid-19-crisis geillustreerd dat de staatssteunregels de interne markt niet kunnen beschermen tegen een ongelijk speelveld tussen de lidstaten vanwege de grote verschillen in de beschikbare steunbudgetten om de nationale economieën te ondersteunen. Anders dan sommige auteurs hebben geopperd bieden de staatssteunregels geen ruimte voor een solidariteitsbijdrage om de concurrentie tussen de lidstaten te beschermen. ${ }^{55}$ De staatssteunregels geven de randvoorwaarden voor de verlening van de steun en bevatten uitsluitend remedies die gericht zijn op de bescherming van de concurrentie op de markt(en) waarop de begunstigde onderneming actief is. Met het Europese herstelfonds, waarover de Europese regeringsleiders op 21 juli 2020 overeenstemming hebben bereikt, wordt nu beoogd het ongelijke speelveld tussen de lidstaten via de Europese begroting te herstellen. Dit herstelfonds maakt steun in de vorm van leningen en subsidies ook voor de minder welvarende lidstaten beschikbaar, zodat zij eveneens kunnen investeren in de groene en digitale transitie van de nationale economieën. ${ }^{56}$ Het is nog te vroeg om te beoordelen of dit herstelfonds zal leiden tot een verschuiving van bepaalde steunmaatregelen van nationaal naar Europees niveau. Daarmee zou het herstelfonds in ieder geval een belangrijk instrument vormen voor de daadwerkelijke Europese aanpak van de huidige en eventuele toekomstige crises. Uit het oogpunt van de bescherming van de interne markt als geheel is een aanpak op Europees niveau het meest adequaat. Het lijkt echter niet aannemelijk dat lidstaten zich de autonomie over het verlenen van nationale steun snel zullen laten ontnemen, waardoor de functie van het herstelfonds (in ieder geval voorlopig) beperkt zal blijven tot het in balans brengen van het evenwicht tussen de lidstaten.

\section{Toepassing kartelverbod en verbod misbruik machtspositie in huidige Covid-19-crisis}

Anders dan de staatssteunregels bevatten artikel 101 en 102 VWEU geen onderdelen die expliciet voorzien in een mogelijkheid van een flexibeler regime in tijden van

55. A. Lamadrid de Pablo en J.L. Buendía, 'A Moment of Truth for the EU: A Proposal for a State Aid Solidarity Fund', Chillin'Competition (https:// chillingcompetition.com/2020/03/31/a-moment-of-truth-for-the-eu-aproposal-for-a-state-aid-solidarity-fund/).

56. Zie de Mededeling van de Commissie aan het Europees Parlement, de Europese Raad, de Raad, het Europees Economisch en sociaal comité en het comité van de regio's, Het moment van Europa: herstel en voorbereiding voor de volgende generatie, $\operatorname{COM}(2020) 456$ final. Zie ook https://ec.europa.eu/info/live-work-travel-eu/health/coronavirusresponse/recovery-plan-europe_nl. Zie hieromtrent ook de bijdrage van H.A.G. Temmink, 'De covid-19-maatregelen van de EU: buigen of barsten?' NtEr 2020/3-4. 
crisis. Hoewel deze bepalingen in tijden van crisis onverkort gelden, dient bij de toepassing hiervan rekening te worden gehouden met de drastisch gewijzigde marktomstandigheden. Zoals hiervoor reeds is aangegeven, hebben deze gewijzigde marktomstandigheden geleid tot enerzijds tekorten in de essentiële sectoren en anderzijds tot grote overschotten in sectoren waar de vraag plotseling is weggevallen. De uitdagingen waar ondernemingen voor staan als gevolg van deze gewijzigde omstandigheden, kunnen aanleiding geven tot onderlinge samenwerkingsvormen. Vanuit een mededingingsrechtelijk perspectief rijst dan echter de vraag welke vormen van samenwerkingen zijn toegestaan.

Om ondernemingen meer duidelijkheid te geven over de toepassing van de mededingingsregels tijdens de Covid-19-crisis hebben diverse nationale mededingingsautoriteiten en het European Competition Network (ECN) verklaringen afgegeven. ${ }^{57}$ Daarnaast is de Commissie in een Tijdelijk Raamwerk ingegaan op de mededingingsrechtelijke beoordeling van samenwerkingen in urgente situaties verbandhoudend met de Covid-19-uitbraak. ${ }^{58}$ De Commissie gaat in het bijzonder in op samenwerkingen tussen ondernemingen die tot doel hebben de adequate productie en distributie van essentiële schaarse producten en diensten tijdens de Covid-19-uitbraak te waarborgen, in het bijzonder van geneesmiddelen en medische hulpmiddelen. Het Tijdelijk Raamwerk geeft de belangrijkste criteria waaraan deze specifieke samenwerkingen moeten voldoen. Vanwege de noodzaak om snel tot een samenwerking te komen en adequaat te kunnen reageren op de ontstane situatie als gevolg van de Covid-19-uitbraak is de Commissie tevens bereid met een zogenoemde comfort letter meer rechtszekerheid te bieden. Dit zijn ambtelijke brieven van de Commissiediensten waarin ad hoc (informele) guidance wordt gegeven over de toelaatbaarheid van een voorgenomen samenwerking. Comfort letters waren vóór de invoering van Verordening (EG) nr. 1/2003 gangbare praktijk. Ondernemingen die zekerheid wensten over de toelaatbaarheid van hun samenwerkingsovereenkomst, konden bij de Commissie een ontheffingsverzoek indienen op grond van artikel 2 Verordening (EEG) nr. 1962/17. Het afgeven van een comfort letter stelde de Commissie in staat een groot deel van die ontheffingsverzoeken informeel af te doen. Deze

57. Zie o.a. ECN, 'Antitrust: Joint statement by the European Competition Network (ECN) on application of competition law during the Corona crisis', 23 maart 2020, zie: https://ec.europa.eu/competition/ecn/ 202003_joint-statement_ecn_corona-crisis.pdf; CMA， 'COVID-19: CMA approach to essential business cooperation, 25 maart 2020, zie: www.concurrences.com/en/bulletin/news-issues/march-2020/the-ukcompetition-authority-issues-guidance-on-business-cooperationduring-the-COVID-19-crisis; Europese Commissie, 'Coronavirus: Commission announces exceptional measures to support the agri-food sector', Nieuwsbericht 22 april 2020, zie: https://ec.europa.eu/ commission/presscorner/detail/en/IP_20_722.

58. Mededeling van de Europese Commissie van 8 april 2020, Tijdelijk Raamwerk voor de beoordeling van mededingingskwesties met betrekking tot samenwerking tussen bedrijven in respons op noodsituaties voortvloeiend uit de huidige COVID-19-uitbraak, PbEU 2020, C 116 I/02 (hierna: 'Tijdelijk Raamwerk') comfort letters werden ook veelal niet gepubliceerd. Met de invoering van Verordening (EG) nr. 1/2003 is het systeem van aanmelding van voorgenomen samenwerkingen, ontheffingsverzoeken en dus ook van comfort letters komen te vervallen. Daarvoor in de plaats kwam een systeem van self assessment: ondernemingen die willen samenwerken moeten sindsdien zelf nagaan of hun voorgenomen samenwerking toelaatbaar is op grond van artikel 101 lid 1 en lid 3 VWEU. Terwijl ook in tijden van crisis ondernemingen in beginsel zelf moeten beoordelen of een samenwerking toelaatbaar is, maakt de comfort letter tijdens deze Covid-19-crisis zijn comeback.

Ten aanzien van de toelaatbare vormen van samenwerking in het Tijdelijk Raamwerk schrijft de Commissie: 'In de huidige uitzonderlijke omstandigheden, [zijn] dergelijke maatregelen niet problematisch uit oogpunt van het EU-mededingingsrecht of zouden zij, gezien de noodsituatie en het tijdelijke karakter ervan, geen handhavingsprioriteit voor de Commissie worden.' ${ }^{59}$ Uit het Tijdelijk Raamwerk volgt niet eenduidig wat de juridische grondslag is voor de toelaatbaarheid van de beschreven samenwerkingen. De samenwerkingen zouden geheel buiten de werkingssfeer van artikel 101 lid 1 VWEU kunnen vallen, bijvoorbeeld omdat ze procompetitief zijn en daardoor niet mededingingsbeperkend. Ook kan het kartelverbod niet op de samenwerkingen van toepassing zijn vanwege bepaalde efficiëntievoordelen voor afnemers of consumenten. ${ }^{60}$ Daarnaast kan de juridische grondslag zijn gelegen in doelstellingen van algemeen belang ${ }^{61}$ of is simpelweg sprake van een beleidskeuze van de Commissie om niet handhavend op te treden.

In het Tijdelijk Raamwerk benadrukt de Commissie verder dat zij niet zal tolereren dat ondernemingen met een machtspositie de Covid-19-crisis gebruiken als dekmantel voor misbruik van hun positie. ${ }^{62}$ Het kan hierbij gaan om ondernemingen die reeds voorafgaand aan de Covid-19-uitbraak over een machtspositie beschikten (bijvoorbeeld specifieke farmaceuten), of juist om ondernemingen die door de specifieke omstandigheden tijdens de Covid-19-crisis een machtspositie hebben verworven (bijvoorbeeld producenten van essentiële schaarse producten zoals medische hulpmiddelen). Qua type misbruik kan onder meer gedacht worden aan het uitbuiten van afnemers of consumenten door het in rekening brengen van excessieve prijzen of uit het beperken van de productie van essentiële schaarse producten. Bij de beoordeling van misbruik van machtspositie zal eveneens rekening moeten worden gehouden met de gewijzigde economische context.

59. Tijdelijk Raamwerk, punt 15

60. De juridische grondslag voor de toelaatbaarheid is dan gelegen in art. 101 lid 3 VWEU.

61. HvJ 19 februari 2002, zaak C-309/99, ECLI:EU:C:2002:98, Jur. 2002 I-01577 (Wouters), punt 97.

62. Tijdelijk Raamwerk, par 20. Zie ook ECN, 'Antitrust: Joint statement by the European Competition Network (ECN) on application of competition law during the Corona crisis', 23 maart 2020, zie: https:// ec.europa.eu/competition/ecn/202003_joint-statement_ecn_coronacrisis.pdf. 


\section{Tijdelijk Raamwerk - flexibel mededingingsregime tijdens COVID-19-crisis}

\section{Algemeen}

De tijdelijke mededingingsregimes die door mededingingsautoriteiten zijn aangekondigd, ${ }^{63}$ zijn in de media ten onrechte als versoepelingen bestempeld. ${ }^{64}$ Diverse auteurs spraken over een flexibelere toepassing van het mededingingsrecht in deze uitzonderlijke omstandigheden. ${ }^{65}$ Hoewel de Commissie voor de agrifoodsector tijdelijke uitzonderingen van het kartelverbod heeft vastgesteld ${ }^{66}$ en door een aantal autoriteiten, waaronder de Commissie, handhavingsprioriteiten zijn gecommuniceerd, betreffen de aankondigingen ten aanzien van de toelaatbaarheid van bepaalde samenwerkingsvormen overwegend de gewijzigde interpretatie van de mededingingsregels als gevolg van de ingrijpend gewijzigde economische context. Enerzijds kunnen bepaalde samenwerkingsvormen de mededinging door de gewijzigde omstandigheden niet merkbaar beperken en vallen ze daarmee niet onder het kartelverbod van artikel 101 lid 1 VWEU. Anderzijds kunnen samenwerkingsvormen belangrijke efficiëntievoordelen genereren die noodzakelijk zijn om bijvoorbeeld het marktfalen als gevolg van de Covid-19-inperkingsmaatregelen het hoofd te bieden. ${ }^{67}$ De voordelen van een dergelijke samenwerking wegen in de huidige economische omstan-

63. Zie o.a. ECN, 'Antitrust: Joint statement by the European Competition Network (ECN) on application of competition law during the Corona crisis', 23 maart 2020, zie: https://ec.europa.eu/competition/ecn/ 202003_joint-statement_ecn_corona-crisis.pdf; CMA, 'COVID-19: CMA approach to essential business cooperation, 25 maart 2020, zie: www.concurrences.com/en/bulletin/news-issues/march-2020/the-ukcompetition-authority-issues-guidance-on-business-cooperation-

during-the-COVID-19-crisis; Europese Commissie, 'Coronavirus: Commission announces exceptional measures to support the agri-food sector', Nieuwsbericht 22 april 2020, zie: https://ec.europa.eu/ commission/presscorner/detail/en/IP_20_722.

64. 'ACM versoepelt concurrentieregels vanwege coronacrisis', Het Financieele Dagblad 19 maart 2020, zie: https://fd.nl/economie-politiek/ 1338378/acm-versoepelt-concurrentieregels-vanwege-coronacrisis.

65. Zie o.a. C. Krohs, A.L. Hamilton en M. Küttner, 'Collaboration among competitors \& COVID-19: The impact on EU and national case laws', Concurrences 9 april 2020, zie: www.concurrences.com/en/bulletin/ special-issues/competition-law-covid-19-en/collaboration-amongcompetitors-covid-19-the-impact-on-eu-and-national-case-en.

66. Zie Uitvoeringsverordening (EU) 2020/599 van de Commissie van 30 april 2020 waarbij toestemming wordt verleend voor overeenkomsten en besluiten betreffende productieplanning in de sector melk en zuivelproducten, PbEU 2020, L 140/37, Uitvoeringsverordening (EU) 2020/594 van de Commissie van 30 april 2020 tot verlening van toestemming voor overeenkomsten en besluiten inzake marktstabiliserende maatregelen in de sector levende planten en producten van de bloementeelt, PbEU 2020, L 140/17, Uitvoeringsverordening (EU) 2020/593 van de Commissie van 30 april 2020 tot verlening van toestemming voor overeenkomsten en besluiten inzake marktstabiliserende maatregelen in de sector aardappelen, PbEU 2020, L 140/13 en Uitvoeringsverordening (EU) 2020/975 van de Commissie van 6 juli 2020 tot verlening van toestemming voor overeenkomsten en besluiten inzake marktstabiliserende maatregelen in de wijnsector, PbEU 2020, L 215/13.

67. HvJ 19 oktober 1986, zaak C-75/84, ECLI:EU:C:1986:399, Jur. 1986, p. I-03021 (Metro/Commissie), punt 41 en 43 . Vgl. ook HvJ 27 januari digheden zwaarder dan de nadelen voor de mededinging (art. 101 lid 3 VWEU), waardoor het kartelverbod niet van toepassing is. ${ }^{68}$ Rechtvaardigen de huidige omstandigheden een bepaalde samenwerking niet, dan is deze samenwerking ook gedurende de Covid-19-crisis verboden en kunnen autoriteiten bij ontdekking van een dergelijke samenwerking daartegen in beginsel handhavend optreden.

Het Tijdelijk Raamwerk geeft derhalve een tijdelijk beoordelingskader voor de toepassing van artikel 101 VWEU in de huidige uitzonderlijke omstandigheden. De regels die moeten worden toegepast, zijn niet versoepeld of gewijzigd. Alleen de omstandigheden die moeten worden betrokken in die beoordeling of aan de regels wordt voldaan, zijn (tijdelijk) wezenlijk veranderd.

\section{Welke samenwerkingen zijn nu praktisch toegestaan?}

Het Tijdelijk Raamwerk somt een aantal vormen van samenwerking in de gezondheidszorg op die de Commissie in de huidige omstandigheden niet problematisch acht vanuit een mededingingsrechtelijk perspectief. De eerste categorie betreft samenwerkingen in de gezondheidszorg waarbij een derde partij (bijvoorbeeld een brancheorganisatie), kort gezegd, in kaart brengt voor welke essentiële geneesmiddelen mogelijk tekorten gaan ontstaan en welke farmaceuten deze tekorten zouden kunnen opvangen. ${ }^{69}$ Zolang bij deze vorm van samenwerking geen gedetailleerde strategische informatie wordt gedeeld tussen concurrenten die herleidbaar is tot individuele ondernemingen, is deze manier van samenwerking toegestaan. Hoewel aan een dergelijke vorm van samenwerking voor de Covid-19-uitbraak wellicht minder behoefte was, lijkt het aannemelijk dat een dergelijke vorm van samenwerking gericht op het voorkomen van tekorten en waarbinnen geen verboden informatie-uitwisseling plaatsvindt, ook vóór de crisis al buiten de werkingssfeer van artikel $101 \mathrm{VWEU}$ viel.

De tweede categorie samenwerkingen die de Commissie beschrijft, is verstrekkender. Het betreft samenwerkingen in de gezondheidszorg waarbij tussen ondernemingen afstemming plaatsvindt (eventueel door het uitwisselen van concurrentiegevoelige informatie) gericht op het optimaliseren van productie. Deze samenwerkingen beogen te voorkomen dat één of enkele farmaceuten focussen op de productie van bepaalde geneesmiddelen,

1987, zaak C-45/85, ECLI:EU:C:1987:34, Jur. 198700405 (Verband der Sachversicherer/Commissie), punt 15

68. Zie ook ECN, 'Antitrust: Joint statement by the European Competition Network (ECN) on application of competition law during the Corona crisis', 23 maart 2020, zie: https://ec.europa.eu/competition/ecn/ 202003_joint-statement_ecn_corona-crisis.pdf.

69. De Commissie noemt samenwerkingen in de gezondheidszorg waarbij een brancheorganisatie (1) het gezamenlijk transport van grondstoffen coördineert; (2) bijdraagt aan het identificeren van essentiële geneesmiddelen waarvoor het risico bestaat dat tekorten ontstaan; (3) geaggregeerde productie en capaciteitsinformatie verzamelt (zonder daarbij informatie te delen die te herleiden is naar individuele ondernemingen); (4) werkt aan een model om op het niveau van de lidstaten vraag naar bepaalde producten in kaart te brengen; en (5) geaggregeerde informatie over mogelijke tekorten deelt teneinde te bezien of ondernemingen die tekorten kunnen opvangen. 
terwijl andere kampen met ondercapaciteit ten aanzien van andere geneesmiddelen. Voor deze vormen van samenwerking geldt dat zij enkel zijn toegestaan of in ieder geval tijdelijk geen handhavingsprioriteit voor de Commissie vormen, indien zij (1) gericht zijn op en noodzakelijk zijn voor het op de meest efficiënte wijze verhogen van de output om tegemoet te komen aan tekorten aan essentiële producten en diensten; (2) tijdelijk van aard zijn; en (3) niet verder gaan dat wat strikt noodzakelijk is om tekorten te adresseren en te voorkomen. ${ }^{70}$

Hoewel het Tijdelijk Raamwerk ondernemingen guidance biedt ten aanzien van samenwerkingen die gericht zijn op de productie en distributie van essentiële schaarse producten en diensten, in het bijzonder in de gezondheidszorg, biedt het geen handvatten voor ondernemingen die zich hiermee niet bezighouden maar wel degelijk geconfronteerd worden met de gevolgen van de Covid-19-crisis en willen samenwerken. Die ondernemingen zijn aangewezen op de algemene guidance die te vinden is in de Richtsnoeren horizontale samenwerkingen, ${ }^{71}$ de Richtsnoeren betreffende toepassing van artikel 101 lid 3 VWEU, ${ }^{72}$ de diverse groepsvrijstellingen en de jurisprudentie. Ook zouden ondernemingen de Commissie kunnen vragen om een comfort letter ten aanzien van de toelaatbaarheid van de beoogde samenwerking.

De crisis biedt geen rechtvaardiging voor vormen van samenwerking gericht op het verminderen van structurele overcapaciteit in een bepaalde bedrijfstak (de zogenoemde 'crisiskartels'). ${ }^{73}$ Uit het $B I D S$-arrest ${ }^{74}$ volgt dat dergelijke crisiskartels als een doelbeperking worden gezien. ${ }^{75}$ Dergelijke vormen van samenwerking zullen niet snel aan de voorwaarden van artikel 101 lid 3 VWEU voldoen, omdat de efficiëntievoordelen veelal beperkt zijn en in ieder geval nauwelijks ten goede komen aan de gebruikers. Daarnaast kunnen minder beperkende maatregelen, waaronder een fusie of overname, ook uitkomst bieden. Zoals hiervoor reeds aangegeven, geldt een bijzondere uitzondering voor bepaalde crisiskartels in de agrifoodsector. De Commissie heeft op grond van artikel 222 GMO-Verordening ${ }^{76}$ uitvoeringsverordeningen vastgesteld voor de zuivel-, sier-

70. Tijdelijk Raamwerk, par.15.

71. Mededeling van de Commissie, Richtsnoeren inzake de toepasselijkheid van artikel 101 van het Verdrag betreffende de werking van de Europese Unie op horizontale samenwerkingsovereenkomsten, $\mathrm{PbEU}$ 2011, C 11/01.

72. Mededeling van de Commissie, Richtsnoeren betreffende de toepassing van artikel 81, lid 3, van het Verdrag, PbEU 2004, C 101/08.

73. Voor een uitgebreide beschrijving van (de economische achtergrond van) crisiskartels wordt verwezen naar D.W.L.A. Schrijvershof, 'Mededingingsrecht in economisch zware tijden: de (on)mogelijkheden voor crisiskartels', Mededingingsrecht in de praktijk 2012, nr. 1, p. 9-20.

74. HvJ november 2008, zaak C-209/07, ECLI:EU:C:2008:643 (BIDS), punt 39.

75. BIDS, punt 40

76. Verordening (EU) nr. 1308/2013 van het Europees Parlement en de Raad van 17 december 2013 tot vaststelling van een gemeenschappelijke ordening van de markten voor landbouwproducten en tot intrekking van de Verordeningen (EEG) nr. 922/72, (EEG) nr. 234/79, (EG) nr. 1037/2001 en (EG) nr. 1234/2007 van de Raad, PbEU 2013, L 347/671. teelt-, wijn- en fritesaardappelsector op grond waarvan artikel 101 lid $1 \mathrm{VWEU}$ tijdelijk niet van toepassing is op bepaalde overeenkomsten en besluiten in deze sectoren.

\section{Comeback van comfort letters?}

Ondernemingen die willen samenwerken, moeten zelf beoordelen of de beoogde samenwerking al dan niet in strijd is met het kartelverbod (self assessment). In haar Tijdelijk Raamwerk geeft de Commissie aan dat ondernemingen in de huidige omstandigheden mogelijk specifieke guidance nodig hebben om deze beoordeling uit te voeren. Om die guidance snel te kunnen geven, is de Commissie 'exceptionally and at its own discretion' bereid deze guidance te bieden in de vorm van ad hoc comfort letters. Ondernemingen zijn uiteraard niet verplicht om deze guidance te vragen.

Nadat de praktijk van comfort letters verdween met de invoering van Verordening (EG) nr. 1/2003, is zij nu in ieder geval tijdelijk terug van weggeweest. Het karakter van een comfort letter is informeel en als zodanig niet bindend voor een nationale rechter of de Commissie zelf. In het verleden kwam het wel voor dat de Commissie een zaak waarin een comfort letter was afgegeven, na een klacht van een concurrent alsnog heropende. ${ }^{77}$ Een formele zekerheid over de toelaatbaarheid van de voorgenomen samenwerking bieden de comfort letters dus niet. Het risico dat een onderneming op een later moment alsnog geconfronteerd wordt met sanctionering door de Commissie of een nationale mededingingsautoriteit of een beroep op nietigheid van bijvoorbeeld een contractspartij vanwege een inbreuk op het kartelverbod voor de nationale rechter, lijkt ten aanzien van voorgenomen samenwerkingen in de huidige crisis evenwel beperkt, zeker gezien het uitzonderlijke en tijdelijke karakter van de samenwerkingen waarvoor de comfort letters worden afgegeven. ${ }^{78}$

Het Directoraat-Generaal Mededinging heeft direct op de dag van publicatie van het Tijdelijk Raamwerk de eerste comfort letter afgegeven aan Medicines for Europe. Hoewel deze comfort letter wél gepubliceerd is, heeft deze geen andere juridische status dan de comfort letters die vóór de inwerkingtreding van Verordening (EG) nr. 1/2003 werden afgegeven. De publicatie heeft wel tot voordeel dat transparant is hoe de Commissiediensten tegen bepaalde samenwerkingsvormen aankijken. Met het oog op de publicatie zullen deze diensten de comfort letter ook niet lichtvaardig afgeven. Het voordeel van de comfort letters is met name gelegen in de snelheid waarmee ze kunnen worden afgegeven.

77. F. Montag, 'The Case for a Reform of Regulation 17/62: Problems and Possible Solutions from a Practioner's Point of View', Fordham International Law Journal 1998, p. 827. Zie ook HvJ EG 10 juli 1980, zaak C-37/79, ECLI:EU:C:1980:190 (Anne Marty SA/Eestee Lauder SA), punt 9 en 10

78. In de comfort letter voor Medicines for Europe geeft de Commissie het volgende aan: 'The cooperation will be limited in time until the risk of shortages, including in a possible second wave of the COVID-19 epidemic, is overcome. The Commission may inform MfE, when this is the case.' 
Uit de formulering dat de Commissie 'exceptionally and at its own discretion' bereid is comfort letters af te geven, blijkt dat de Commissie alleen tijdelijk en slechts in deze uitzonderlijke omstandigheden comfort letters zal afgeven. Het permanent toevoegen van comfort letters aan haar instrumentarium lijkt ook niet te stroken met de doelstellingen van de invoering van Verordening (EG) nr. 1/2003: zorgen voor een efficiënte handhaving van de mededingingsregels door het vroegere aanmeldingssysteem af te schaffen, de eigen beoordeling van voorgenomen samenwerkingen door partijen centraal te stellen (self-assessment) en de Commissie zo in staat te stellen haar handhavingsbeleid te richten op de zwaarste inbreuken. ${ }^{79}$

Verordening (EG) nr. 1/2003 voorziet nog in twee andere vormen van guidance. Ten aanzien van een nieuwe of onopgeloste vraag over de toepassing van artikel $101 \mathrm{VWEU}^{80}$ kunnen ondernemingen de Commissie om een informeel niet bindend advies vragen. ${ }^{81}$ Daarnaast geeft artikel 10 Verordening (EG) nr. 1/2003 de Commissie de mogelijkheid ambtshalve bij beschikking vast te stellen dat artikel $101 \mathrm{VWEU}$ niet van toepassing is op een overeenkomst, een besluit van een ondernemersvereniging of een onderling afgestemde feitelijke gedraging, hetzij omdat niet aan de voorwaarden van artikel 101 lid 1 VWEU is voldaan, hetzij omdat aan de voorwaarden van artikel 101 lid $3 \mathrm{VWEU}$ is voldaan. In de praktijk is - voor zover bekend - geen van deze instrumenten gebruikt (ook niet buiten crisistijd). Deze instrumenten lijken in de huidige crisissituatie ook minder geschikt, omdat hiervoor een formalistischer (en dus ook tijdrovender) procedure moet worden gevolgd. Anders dan ten aanzien van de staatssteunregels is de materiële beoordeling minder uitgewerkt in specifieke kaders en is een beoordeling van geval tot geval vereist die (meer) tijd vergt.

\section{Vooruitblik}

Zoals hiervoor reeds opgemerkt is de geboden flexibiliteit ten aanzien van de toepassing van artikel 101 VWEU in beginsel geen versoepeling van de regel zelf, maar een meebuigen van de toepassing daarvan met de ingrijpend gewijzigde economische context. Het is derhalve niet aannemelijk dat de tijdens de huidige crisis toegepaste flexibiliteit een blijvende wijziging van de toepassing van artikel $101 \mathrm{VWEU}$ inhoudt. Indien de marktsituatie weer normaliseert, door o.a. de opheffing van de inperkingsmaatregelen en het herstel van de vraag- en aanbodzijde, is de genormaliseerde marktsituatie immers weer het referentiekader voor de toepassing van de mededingingsregels. Datzelfde geldt voor de

79. Verordening (EG) nr. 1/2003, overweging 3.

80. Of art. 102 VWEU.

81. Mededeling van de Commissie over informeel advies betreffende nieuwe vragen met betrekking tot de artikelen 81 en 82 van het EG-Verdrag die in individuele gevallen rijzen (adviesbrieven), $P b E G$ 2004, C 101/06, par. 5, 7 en 25. prioritering in het handhavingsbeleid voor zover dat ertoe strekt om tijdelijk bepaalde inbreuken te gedogen, bijvoorbeeld de uitwisseling van informatie in specifieke situaties. Ook lijkt de rol van de comfort letter beperkt te blijven tot de huidige crisis en zijn er geen aanwijzingen dat deze zijn permanente comeback heeft gemaakt.

Niettemin heeft de crisis inzichtelijk gemaakt dat er naast concurrentie om de laagste prijs ook andere belangen zijn die aandacht behoeven om markten (vooral in tijden van crisis) zo goed mogelijk te laten functioneren. ${ }^{82}$ Ten aanzien van de essentiële producten zijn de belangen als beschikbaarheid, zelfvoorzienendheid en kwaliteit zeer duidelijk geworden. Voor zover deze belangen voor de crisis niet als een efficiëntievoordeel van een bepaalde samenwerkingsvorm zouden zijn geaccepteerd omdat een mondiale verstoring van de toeleveringsketens niet als een realistisch scenario werd gezien, lijkt het aannemelijk dat de waardering van dergelijke efficiëntievoordelen als gevolg van de crisis is gewijzigd. Weliswaar zal de ruimte voor dergelijke samenwerkingsvormen na de crisis niet dezelfde zijn als tijdens de crisis, maar voor een zekere samenwerking die gericht is op het waarborgen van de continuiteit en kwaliteit van een bepaald (minimum)voorzieningenniveau van essentiële producten lijkt ook na de crisis meer ruimte te bestaan. Dit roept de vraag op of we eerst de gevolgen van een crisis moeten ondervinden alvorens het belang van een bepaalde samenwerkingsvorm op waarde wordt geschat en een plaats krijgt binnen de mededingingsregels. Het recent door de Autoriteit Consument \& Markt gepubliceerde consultatiedocument over de conceptleidraad duurzaamheidsafspraken lijkt een aanwijzing dat er (gelukkig) niet eerst een klimaatcrisis nodig zal zijn om de belangen van duurzaamheid en het behalen van de klimaatdoelen, zoals de vermindering van de $\mathrm{CO}_{2}$-uitstoot, een plaats te geven binnen de mededingingsregels. ${ }^{83}$ Ook op Europees niveau lijken deze belangen een plek te krijgen in het kader van de herziening van de richtsnoeren voor horizontale samenwerkingsvormen door de Commissie. ${ }^{84}$

\section{Conclusie}

In tijden van crisis kunnen de mededingingsregels meebuigen met de gewijzigde economische context. De mate waarin deze flexibiliteit ruimte biedt voor aanvullende steunmaatregelen en initiatieven om de economie te ondersteunen, heeft de Commissie uitgewerkt in tijdelijke kaders. De benutting van de ruimte die deze tijdelijke flexibele kaders bieden, is in ieder geval op het gebied van staatssteun zeer zichtbaar. In korte tijd is een groot aantal steunmaatregelen door de Commissie goedgekeurd. Op het gebied van het kartelverbod en verbod

82. Zie bijvoorbeeld 'De mededinging dood? Leve de mededinging', Het Financieele Dagblad 30 juni 2020.

83. Zie www.acm.nl/nl/publicaties/concept-leidraad-duurzaamheids afspraken.

84. Zie https://ec.europa.eu/competition/antitrust/news.html. 
op misbruik van machtspositie is minder zichtbaar of de aanvullende ruimte voor samenwerkingsvormen wordt benut. Van de comfort letter lijkt in de praktijk nog niet veel gebruik te worden gemaakt.

Omdat de flexibiliteit van de mededingingsregels afhankelijk is van de economische omstandigheden is het niet aannemelijk dat de tijdelijke kaders zullen leiden tot blijvende wijzigingen van de mededingingsregels. Wel draagt de geboden flexibiliteit bij aan de acceptatie van de toepassing van de mededingingsregels in crisistijd, hetgeen cruciaal is voor de bescherming van de interne markt.

De Covid-19-crisis heeft echter ook zichtbaar gemaakt dat de disciplinerende werking van de mededingingsregels en in het bijzonder de staatssteunregels beperkingen kent. Door de grote verschillen tussen de steunbudgetten van de lidstaten is een ongelijk speelveld ontstaan tussen de lidstaten. Het is derhalve van belang dat de flexibiliteit van de staatssteunregels onderdeel is van een breder pakket aan maatregelen om de interne markt te beschermen tegen de ingrijpende economische gevolgen van de Covid-19-inperkingsmaatregelen. ${ }^{85}$ Het ingerichte herstelfonds vormt daarbij een cruciaal onderdeel. Voor het herstel van de interne markt is niet alleen flexibiliteit, maar ook solidariteit noodzakelijk teneinde de gezamenlijke EU-doelstellingen ten aanzien van de groene en digitale transitie voor de gehele interne markt te kunnen realiseren. 